\title{
Familial Glucocorticoid Deficiency: Advances in the Molecular Understanding of ACTH Action
}

\author{
L.F. Chan A.J.L. Clark L.A. Metherell \\ Centre for Endocrinology, William Harvey Research Institute, St. Bartholomew's and The Royal London School of \\ Medicine and Dentistry, London, UK
}

\section{Key Words}

Familial glucocorticoid deficiency $\cdot \mathrm{MC} 2 \mathrm{R} / \mathrm{ACTHR} \cdot \mathrm{MRAP}$. ACTH resistance

\begin{abstract}
Familial glucocorticoid deficiency (FGD), otherwise known as hereditary unresponsiveness to $\mathrm{ACTH}$, is a rare autosomal recessive disease characterized by glucocorticoid deficiency in the absence of mineralocorticoid deficiency. Mutations of the ACTH receptor, also known as the melanocortin-2 receptor (MC2R), account for approximately $25 \%$ of FGD cases. More recently a second gene, MRAP (melanocortin-2 receptor accessory protein), was identified and found to account for a further $15-20 \%$. MRAP encodes a small single transmembrane domain protein, which is essential in the trafficking of the MC2R to the cell surface. In this review, we will firstly summarize the clinical presentation and genetic aetiology of this condition. Secondly, we will discuss how the discovery of MRAP has enhanced our understanding of the mechanisms of ACTH/MC2R action. Finally, we will explore future developments in this field.
\end{abstract}

Copyright ๑ 2007 S. Karger AG, Basel
(C) 2007 S. Karger AG, Basel

0301-0163/08/0692-0075\$24.50/0

Fax +41613061234

E-Mail karger@karger.ch

www.karger.com
Accessible online at:

www.karger.com/hre

\section{Introduction}

Over the past 15 years significant advances have been made in the understanding of the genetic basis of adrenal disease with regard to primary and secondary causes of adrenal insufficiency. The discovery of individual gene defects has contributed to understanding the mechanisms controlling adrenal gland development and steroidogenesis pathways (some examples are shown in table 1). The study of adrenal resistance syndromes, namely triple A syndrome and in particular familial glucocorticoid deficiency (FGD), has provided insight into the mechanism of ACTH action.

We searched PubMed for articles published between 1970 and 2006 using the search terms 'familial glucocorticoid deficiency', 'ACTH resistance' and 'adrenal unresponsiveness'. We also searched the reference lists of identified articles for further papers.

The triple A syndrome is a complex multisystem disorder characterized by adrenal failure, alacrima and achalasia. Not all patients have adrenal involvement, but of those with adrenal insufficiency approximately $80 \%$ will have isolated glucocorticoid deficiency. This condition has been reviewed elsewhere and will not be covered here [1].
Dr. L.A. Metherell

Centre for Endocrinology, John Vane Science Centre

Charterhouse Square

London EC1M 6BQ (UK)

Tel. +44 207882 6241, Fax +44 207882 6197, E-Mail l.a.metherell@qmul.ac.uk 


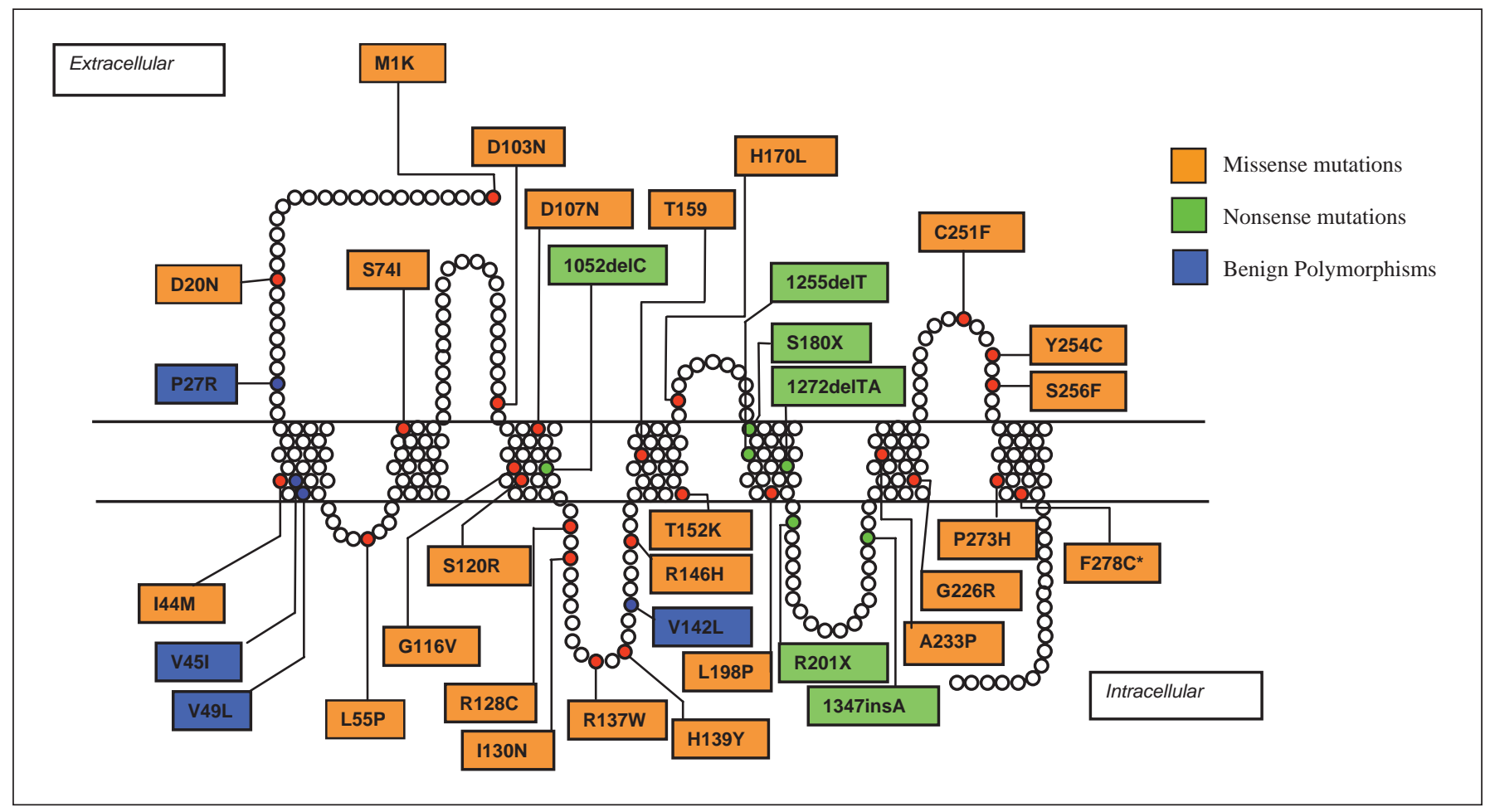

Fig. 1. Schematic diagram of the human MC2R showing the locations of all the known polymorphisms and mutations. Each circle represents an amino acid residue. The * F278C mutation is the only known activating MC2R mutation [reprinted from 62, with permission].

Table 1. Examples of single gene defects in inherited forms of primary adrenal insufficiency

\begin{tabular}{|c|c|c|}
\hline Disease & OMIM & Gene \\
\hline \multicolumn{3}{|l|}{ Congenital adrenal hyperplasia } \\
\hline 21-Hydroxylase deficiency & 201910 & Сур21 \\
\hline $11 \beta$-Hydroxylase deficiency & 202010 & Cyp11B1 \\
\hline \multicolumn{3}{|l|}{$3 \beta$-Hydroxysteroid } \\
\hline dehydrogenase deficiency & 109715 & HSD3B2 \\
\hline $17 \alpha$-Hydroxylase deficiency & 202110 & Cyp17 \\
\hline Lipoid adrenal hyperplasia & 201710 & STAR \\
\hline \multirow[t]{2}{*}{ Congenital adrenal hypoplasia } & 300200 & NR0B1 (DAX-1) \\
\hline & 300473 & NR5A1 (SF-1) \\
\hline \multicolumn{3}{|l|}{ Familial glucocorticoid deficiency } \\
\hline Type 1 & 202200 & MC2R \\
\hline Type 2 & 609196 & MRAP \\
\hline Type 3 & 609197 & unknown \\
\hline Triple A syndrome & 202110 & AAAS \\
\hline X-linked adrenoleucodystrophy & 300371 & ABCD1 \\
\hline \multicolumn{3}{|l|}{ Autoimmune polyglandular } \\
\hline syndrome type 1 & 240300 & AIRE \\
\hline
\end{tabular}

FGD (OMIM 202200) was first described by Shepard et al. [2] in 1959. The report of two siblings with what was called 'familial Addison's disease' prompted subsequent papers describing patients with isolated glucocorticoid deficiency [3-5]. It took a further 30 years before the identification of the first inactivating ACTH receptor mutation in a patient with FGD [6]. Since then a large number of mutations have been found which are summarized in figure 1. The ACTH receptor was the second melanocortin receptor to be cloned hence the alternative nomenclature of MC2R [7].

FGD is characterized by glucocorticoid deficiency in the presence of normal plasma renin and aldosterone levels. Nevertheless, mild derangements of the renin-angiotensin system at the time of diagnosis are sometimes seen with this condition [8], and it has been suggested that a partial mineralocorticoid-deficient state exists in those patients with 'severe genotypes' [9]. This may mean that in some cases a diagnosis cannot be made using clinical and biochemical parameters alone. The finding of mutations in the $M C 2 R$ gene and the more recently described $M R A P$ gene would provide a definitive diagnosis. How- 
ever, genetic defects in $M C 2 R$ and MRAP only account for $40-45 \%$ of cases, leaving the remaining $55-60 \%$ of patients with no identifiable gene defect.

\section{Clinical and Biochemical Features of FGD}

\section{Presentation}

Patients with FGD are usually diagnosed during the neonatal period or by early childhood. They may present with hypoglycaemic seizures, hyperpigmentation, recurrent infections, failure to thrive, collapse and coma. Transient neonatal hepatitis has also been described as a presenting feature [10]. All the symptoms and signs seen in FGD are the result of either hypocortisolaemia or elevated ACTH levels. The long-term neurological consequence of FGD can vary from learning difficulties to spastic quadriplegia, which may reflect the severity and number of hypoglycaemic episodes during childhood [11]. There may be a family history of unexplained neonatal deaths, the presence of another affected family member and/or consanguinity.

\section{Assessment}

FGD can usually be distinguished from other causes of primary adrenal insufficiency by the absence of mineralocorticoid deficiency and associated features seen in such conditions. This would include progressive neurological manifestations (triple A, adrenoleucodystrophy), ambiguous genitalia (congenital adrenal hyperplasia, $\mathrm{CAH}$ ), other dysmorphic features (IMAGe), hypogonadism, delayed puberty (congenital adrenal hypoplasia), alacrima/achalasia (triple A) and presence of other autoimmune deficiencies (polyglandular autoimmune syndromes). These differential diagnoses should always be considered prior to the diagnosis of FGD and in some instances specific investigations may be required. For example, adrenal antibodies, very-long-chain fatty acid measurement, 17-OHP, Schirmer test of tear production together with a barium swallow could help to differentiate autoimmune cause of adrenal insufficiency, adrenoleucodystrophy, $\mathrm{CAH}$ and triple A syndrome, respectively. Monitoring of blood pressure is an essential part of assessment and may diagnose some forms of CAH presenting with hypertension.

\section{Specific Features of FGD}

Tall Stature

Tall stature is observed in some FGD patients with MC2R mutations $[12,13]$. In addition, a proportion of these patients have been shown to have advanced or dissociated bone age, e.g. advanced bone maturation in the radius and phalanges with delay seen in the carpal bones. This excessive growth is more noticeable prior to the initiation of treatment, and although hydrocortisone replacement appears to bring the height back towards the mid-parental target, children remain tall as adults [8]. The rather limited data available suggests that the insulin-like growth factor I-growth hormone axis is normal in these patients [12]. It has been proposed that the excessive growth is due to high plasma ACTH levels [13]. The presence of all five melanocortin receptors in bone and the ability of ACTH to stimulate CAMP production and gene expression in bone cells provide a plausible mechanism $[12,14,15]$. However, not all FGD patients with inactivating mutations of the MC2R are tall, short stature has also been described [16].

\section{Absent Adrenarche}

ACTH is required in the regulation of adrenarche in normal children and absent adrenarche is a feature seen in children with FGD. Clinically this presents as delayed or absent pubic hair development associated with extremely low/undetectable adrenal androgen levels in children $>7$ years of age and those in puberty [17]. Ishii et al. [18] report a FGD patient with sparse pubic hair in adulthood despite normal progression in puberty and regular menses, demonstrating the importance of ACTH in the induction and subsequent maintenance of adrenarche and pubic hair attainment. In contrast, true puberty defined as breast development and subsequent ovarian development, controlled by the hypothalamic-pituitary-gonadal axis, is unaffected in FGD.

\section{Markedly High Plasma ACTH}

Most FGD patients have markedly raised plasma ACTH levels reflecting the extent of resistance. However, suppression of plasma ACTH levels in FGD can be very difficult despite treatment with high doses of hydrocortisone. The reason for this apparent lack of suppression is unclear. There is some suggestion of the existence of a short ACTH negative feedback loop at the level of the pituitary/hypothalamus. Hence, patients with mutations which render the MC2R inactive would lack negative inhibition of ACTH release at this level [19-22].

\section{Hyperpigmentation}

Hyperpigmentation is almost always observed in FGD. The child often develops pigmentation by the 1st month of life and usually remains pigmented despite treatment. 
Pigmentation is generally thought to be due to the high ACTH levels which act on the melanocortin-1 receptors in melanocytes.

\section{Investigations}

Biochemistry

The typical biochemical results in FGD are a combination of low cortisol levels paired with extremely high plasma ACTH levels, in the presence of normal plasma renin and aldosterone. ACTH levels of above $1,000 \mathrm{pg} /$ $\mathrm{ml}$ (normal range $<80 \mathrm{pg} / \mathrm{ml}$ by RIA; $<50 \mathrm{pg} / \mathrm{ml}$ by IRMA) are commonly found $[8,23]$. Occasionally, children may have minor impairment of the renin-angiotensin-aldosterone axis at the time of initial presentation $[8,24]$. The physiological explanation of this observation is unclear. Two factors may play a part. Firstly, there is evidence that ACTH directly activates the production of aldosterone in the zona glomerulosa (ZG). It has been found that MC2R mRNA localizes to the ZG and administration of synthetic ACTH to normal human subjects results in a rise in plasma aldosterone levels [5, 24-27]. The physiological importance of ACTHdependent regulation of aldosterone in normal physiology and disease is undetermined. Interestingly, the ability of ACTH to stimulate aldosterone production may stem from the role of ACTH in the normal organization of the $Z G$ during development of the adrenal gland, as suggested by the abnormal ZG histology seen in patients with FGD (see later). Secondly, during periods of illness and acute stress, changes in the renin-angiotensin-aldosterone axis are seen $[8,28]$. The difficulties in dissecting the biochemical results in a sick child and the potential of misdiagnosing patients presenting with adrenal insufficiency and mild renin-angiotensinaldosterone disturbance were exemplified by Lin et al. [9]. They identified 7 children diagnosed with probable primary adrenal hypoplasia who on genetic evaluation were found to have FGD with MC2R mutations. This enabled the withdrawal of fludrocortisone treatment in a number of patients. However, there was a suggestion that a partial mineralocorticoid-deficient state might exist in some 'MC2R severe loss of function mutations'. Patients with minor changes in renin/aldosterone levels would benefit from re-evaluation as this would have significant implications on their long-term management and genetic counselling $[8,9]$.

Blood glucose monitoring is essential in any child who is unwell and in FGD hypoglycaemia may result in a number of symptoms ranging from failure to thrive to coma. Dynamic testing with the short ACTH stimulation test (Synacthen ${ }^{\circledR}=1-24$ ACTH) will confirm a diagnosis of primary adrenal insufficiency. A normal response is defined as a peak plasma cortisol level of more than 550 nmol/l. There is evidence that some patients with FGD have a normal response to a short Synacthen test initially which on re-testing in later life becomes abnormal (unpubl. observation). Additional investigations may help with differentiating FGD from other causes of primary adrenal insufficiency. For example, detectable adrenal autoantibodies can indicate autoimmune Addison's disease. Elevated levels of very-long-chain fatty acids would suggest adrenoleucodystrophy. Adrenal androgen levels including 17-OHP and urinary steroid chromatography would help to differentiate $\mathrm{CAH}$.

Despite careful clinical and biochemical evaluation some patients may not easily fall into a diagnostic category. In such patients diagnosed with 'primary adrenal insufficiency', mutational analysis of genes such as those listed in table 1 has proved successful [29].

\section{Adrenal Imaging}

Adrenal imaging in the form of MRI/CT scanning can be helpful. In FGD the glands are usually small in size [8]. This is in contrast to tuberculosis (calcified adrenal glands), CAH (enlargement), storage disorders and infiltrative disorders (enlargement of the gland).

\section{Histopathology}

There are several histopathology studies from cases where a sibling has died prior to the diagnosis being made on the index child. These report the absence of fasciculata or reticularis cells together with disorganization of granulosa cells $[2,8,30,31]$.

\section{Treatment}

The treatment is by replacement with hydrocortisone. An oral dose of $10-12 \mathrm{mg} / \mathrm{m}^{2} /$ day in three divided doses in children and $20-30 \mathrm{mg} /$ day in adults is usually sufficient. The suppression of plasma ACTH levels in FGD can be very difficult and should not be used as the goal of treatment. Educating parents and patients on the need to increase hydrocortisone dosages during illness and the emergency management with intramuscular hydrocortisone is vital. Recently, Crown et al. [32] reviewed the management of glucocorticoid deficiency, highlighting controversies that still exist in the 'optimal' treatment regime of such patients. Medic alert bracelet, 'steroid card' and handheld summaries should be given to all patients. 
Fig. 2. Diagram illustrating the transcription and translation of MRAP. Exons 5 and 6 are alternatively spliced to generate the MRAP- $\alpha$ and MRAP- $\beta$ isoforms, respectively. Protein prediction programmes suggest that the N-terminus of these proteins lies on the intracellular cytoplasmic surface of the membrane.

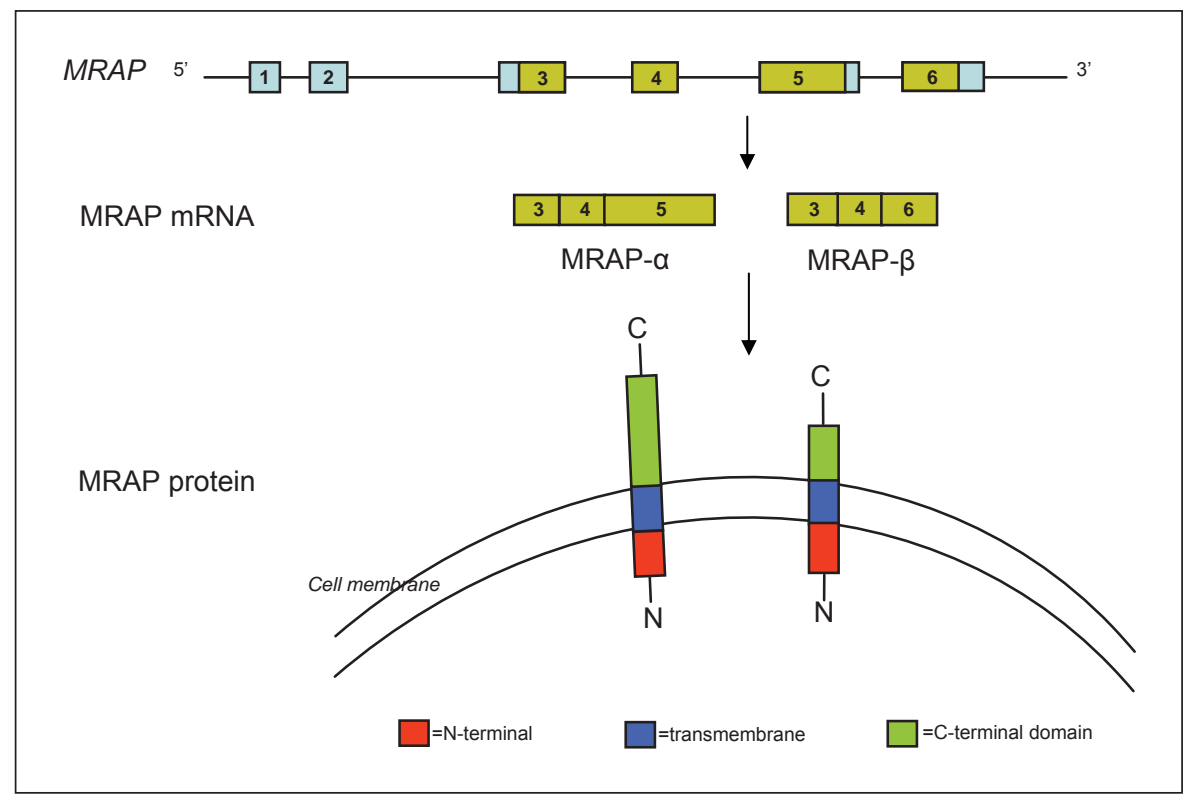

\section{FGD and ACTH Receptor Action}

FGD Type 1 (OMIM*202200) and MC2R Mutations

The cloning of the MC2R by Mountjoy et al. [33] in 1992 enabled researchers to identify point mutations in the ACTH receptor in patients with FGD [34-39]. The MC2R gene, located on chromosome 18q11, encodes a 297-amino acid G-protein-coupled receptor. More than 30 mutations have been described in the MC2R (fig. 1), the majority of which are homozygous missense or compound heterozygous mutations. In comparison, homozygous nonsense mutations are rare. The functional consequence of various MC2R mutations has been demonstrated by a number of groups [36, 40-44]. To date there is no strong evidence to suggest that heterozygous carriers, i.e. parents or siblings of FGD patients, have abnormal cortisol secretion or response. On detailed investigation, Tsigos et al. [34] found that the mother and grandmother of an affected child with the R201X (substitution of an arginine residue at amino acid position 201 with a stop codon) and S120R (serine $\rightarrow$ arginine at position 120) mutations had exaggerated and prolonged ACTH responses to administration of corticotropin-releasing hormone (CRH). This suggests subclinical resistance to ACTH in heterozygous carriers; however, an investigation into 4 patients heterozygous for 4 different MC2R mutations revealed normal responses to $\mathrm{CRH}$ in $3 / 4$ carriers. The 4 th carrier heterozygous for the L192fs (frameshift at the leucine residue, position 192) mutation had an exaggerated increase in plasma ACTH combined with an elevated serum cortisol response to $\mathrm{CRH}$. The findings in this patient were believed to be a stress response to human $\mathrm{CRH}$ administration as a previous ovine CRH test was reportedly normal [36]. CRH responses have been shown to vary according to ethnic background $[45,46]$. The family studied by Tsigos et al. [35] were of black ethnicity which may account for the elevated ACTH response after $\mathrm{CRH}$.

\section{Discovery of MRAP and FGD Type 2}

Mutational screening of the MC2R revealed that MC2R defects could only account for approximately $25 \%$ of cases $[47,48]$. Linkage studies provided evidence of a second FGD locus [49] and, in parallel with this, evidence accumulated of the existence of an 'MC2R' accessory factor [50, 51]. Homozygosity mapping, utilizing SNP (single nucleotide polymorphisms) microarrays across the whole genome, identified a third locus on chromosome 21 in some families with FGD. Fine mapping of the region together with mRNA expression studies of genes within this region revealed a candidate gene, now known as MRAP (melanocortin-2 receptor accessory protein). This gene was found to encode a single transmembrane protein with 2 isoforms of 19 and $11.5 \mathrm{kDa}$ in size derived from alternative splicing of exons 5 and 6 (fig. 2). Functional analysis of the protein revealed four key findings: (1) direct interaction with MC2R, (2) requirement for MC2R function, (3) co-localization with the MC2R and 
Fig. 3. Schematic representation of the human MRAP $\alpha$ protein showing the locations of the mutations identified so far. All 9 mutations result in either an absent or significantly truncated protein of both isoforms.

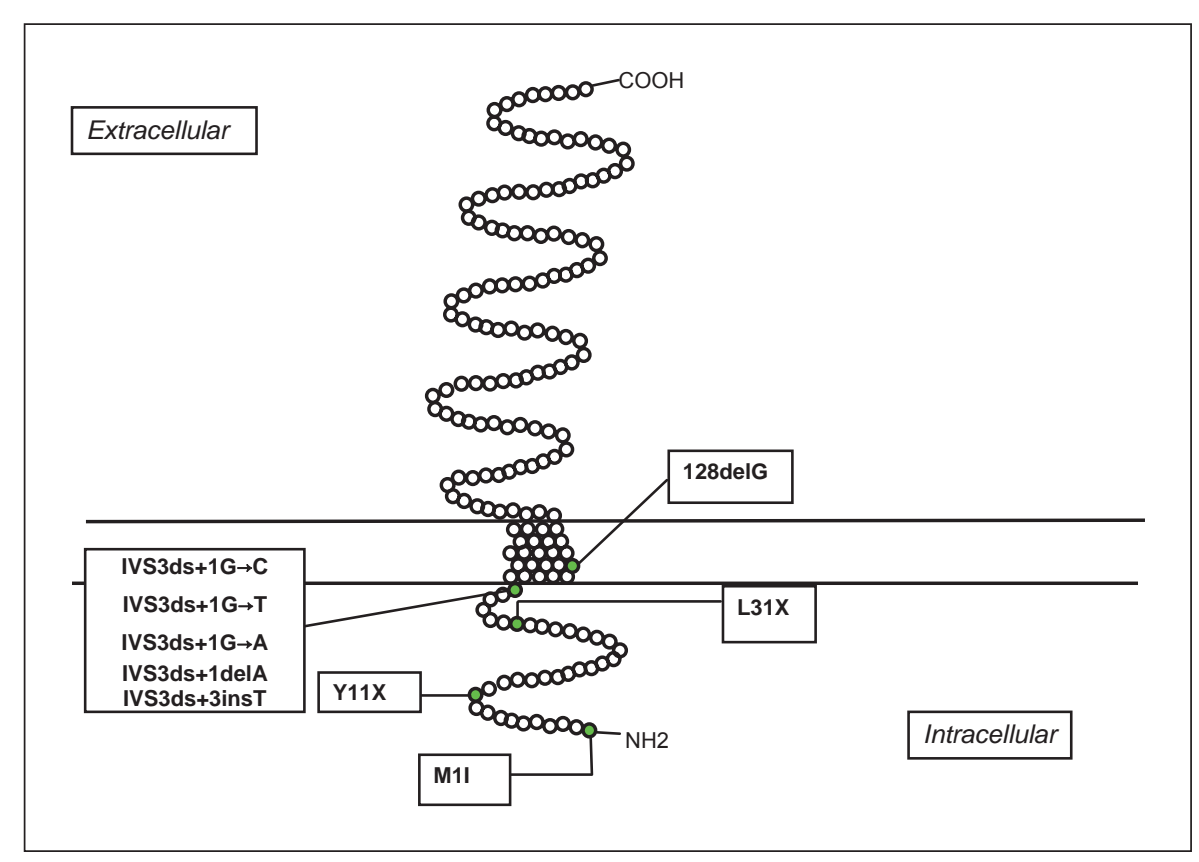

(4) requirement for MC2R cell surface expression [52]. So far our group has identified 8 different mutations of MRAP in FGD patients (publ. and unpubl. data). ModanMoses et al. [11] identified a further mutation consisting of a 7-nucleotide deletion in exon 3 , resulting in a frame shift and a premature stop codon, L31X. These mutations are summarized in figure 3 . In contrast to the MC2R mutations, these mutations would all result in either the complete absence of the protein or a severely truncated product.

\section{Future for FGD Type 3, 4 and Beyond}

FGD type 1 and type 2 refer to patients with MC2R and MRAP mutations, respectively. In clinical samples over $50 \%$ of FGD patients have no identifiable mutation in either gene - this group of patients are referred to as having FGD type 3. Linkage to chromosome 8 has been found in a minority of families with FGD type 3, although a candidate gene has yet to be identified [49], but not all families segregate to chromosome 8 suggesting the involvement of additional genes.

\section{Receptor Accessory Proteins}

The discovery of MRAP has provided a new mechanism of melanocortin receptor regulation which was previously unknown. Small single transmembrane proteins such as the RAMPs, RTPs and REEPs are a growing number of receptor accessory proteins which interact with $G$ protein-coupled receptors [53-55]. These accessory proteins assist receptor trafficking to the cell surface and may be able to determine ligand specificity. MRAP may also have functions in the folding and translocation of the MC2R through the endoplasmic reticulum hence acting as a molecular chaperone. The molecular properties of MRAP are being investigated by a number of groups including our own. Roy et al. [56] recently reported their work looking at the differential regulation of the human MC2R by MRAP isoforms.

\section{Future}

Single gene defects in rare diseases have been crucial to the understanding of a variety of signalling pathways. At the molecular level, CUL-7 in 3-M syndrome [57], P450 oxidoreductase deficiency in Antley-Bixler syndrome [58], and POMC in the syndrome of adrenal insufficiency and red hair [59] are just some of the examples in which the study of rare diseases has provided insight into the respective signalling mechanisms. Homozygosity mapping in consanguineous families has proved to be a highly successful strategy in the mapping of rare recessive traits. One may argue that the identification of such genes in rare diseases may be of limited benefit to the population at large. However, it is difficult to quantify the benefit from improvement in the understanding of the 
molecular biology of the cell. Moreover, it may be that aetiological genes in rare disorders can also play a role in conditions of high relevance to the population at large. An example of this success is the study of the melanocortin- 4 receptor (MC4R) in obesity. MC4R mutations, identified initially as a rare cause of severe obesity in childhood, are now believed to be the most common monogenic cause of obesity in the general population [60,61].

The discovery of mutations in genes that cause FGD now enables a definitive genetic diagnosis of FGD in some cases. Such a diagnostic test not only has relevance for diagnosing new cases of FGD but also revisiting of patients thought to have adrenal failure of unknown cause. Isolated glucocorticoid deficiency should still be considered the norm. However, in cases where there may have been derangements of renin-aldosterone levels at the time of diagnosis and those who may have slight derangements, these children may benefit from review of their mineralocorticoid status and genotyping of the MC2R/MRAP genes.

At present a genetic diagnosis is not possible for a large proportion of patients and the aetiology of FGD type 3 patients needs to be elucidated. It is hoped that such discoveries will shed more light on the ACTH signalling pathway and the diseases which arise when regulation of this pathway fails in underactive and overactive states.

\section{Acknowledgments}

L.F.C. is supported by a Clinical Research Training Fellowship from the Medical Research Centre, and L.A.M. by the Wellcome Trust.

\section{References}

-1 Huebner A, Kaindl AM, Knobeloch KP, Petzold H, Mann P, Koehler K: The triple A syndrome is due to mutations in ALADIN, a novel member of the nuclear pore complex. Endocr Res 2004;30:891-899.

$\checkmark 2$ Shepard TH, Landing BH, Mason DG: Familial Addison's disease; case reports of two sisters with corticoid deficiency unassociated with hypoaldosteronism. AMA J Dis Child 1959;97:154-162.

-3 Thistlethwaite D, Darling JA, Fraser R, Mason PA, Rees LH, Harkness RA: Familial glucocorticoid deficiency. Studies of diagnosis and pathogenesis. Arch Dis Child 1975;50: 291-297.

4 Thistlethwaite D, Darling JA, Fraser R, Rees LH, Harkness RA: Proceedings: familial glucocorticoid deficiency. J Endocrinol 1974;63: 48P-49P.

5 Spark RF, Etzkorn JR: Absent aldosterone response to ACTH in familial glucocorticoid deficiency. N Engl J Med 1977;297:917-920.

6 Clark AJ, McLoughlin L, Grossman A: Familial glucocorticoid deficiency associated with point mutation in the adrenocortico tropin receptor. Lancet 1993;341:461-462.

$\checkmark 7$ Mountjoy KG, Robbins LS, Mortrud MT, Cone RD: The cloning of a family of genes that encode the melanocortin receptors. Science 1992;257:1248-1251.

$>8$ Clark AJ, Weber A: Adrenocorticotropin insensitivity syndromes. Endocr Rev 1998;19: 828-843.

$\checkmark 9$ Lin L, Hindmarsh PC, Metherell LA, Alzyoud M, Al Ali M, Brain CE, et al: Severe lossof-function mutations in the adrenocorticotropin receptor (ACTHR, MC2R) can be found in patients diagnosed with salt-losing adrenal hypoplasia. Clin Endocrinol 2007; 66:205-210.
10 Lacy DE, Nathavitharana KA, Tarlow MJ: Neonatal hepatitis and congenital insensitivity to adrenocorticotropin (ACTH). J Pediatr Gastroenterol Nutr 1993;17:438-440.

11 Modan-Moses D, Ben Zeev B, Hoffmann C, Falik-Zaccai TC, Bental YA, Pinhas-Hamiel $\mathrm{O}$, et al: Unusual presentation of familial glucocorticoid deficiency (FGD) with a novel MRAP mutation. J Clin Endocrinol Metab 2006;91:3713-3717.

12 Elias LL, Huebner A, Metherell LA, Canas A, Warne GL, Bitti ML, et al: Tall stature in familial glucocorticoid deficiency. Clin Endocrinol (Oxf) 2000;53:423-430.

13 Imamine H, Mizuno H, Sugiyama Y, Ohro Y, Sugiura T, Togari H: Possible relationship between elevated plasma ACTH and tall stature in familial glucocorticoid deficiency. Tohoku J Exp Med 2005;205:123-131.

14 Zhong Q, Sridhar S, Ruan L, Ding KH, Xie $\mathrm{D}$, Insogna $\mathrm{K}$, et al: Multiple melanocortin receptors are expressed in bone cells. Bone 2005;36:820-831.

15 Mountjoy KG, Jenny Wu CS, Dumont LM, Wild JM: Melanocortin-4 receptor messenger ribonucleic acid expression in rat cardiorespiratory, musculoskeletal, and integumentary systems. Endocrinology 2003;144: 5488-5496.

16 Selva KA, Lafranchi SH, Boston B: A novel presentation of familial glucocorticoid deficiency (FGD) and current literature review. J Pediatr Endocrinol Metab 2004;17:85-92.

17 Weber A, Clark AJ, Perry LA, Honour JW, Savage MO: Diminished adrenal androgen secretion in familial glucocorticoid deficiency implicates a significant role for ACTH in the induction of adrenarche. Clin Endocrinol (Oxf) 1997;46:431-437.
8 Ishii T, Ogata T, Sasaki G, Sato S, Kinoshita EI, Matsuo N: Novel mutations of the ACTH receptor gene in a female adult patient with adrenal unresponsiveness to ACTH. Clin Endocrinol (Oxf) 2000;53:389-392.

19 Suda T, Yajima F, Tomori N, Sumitomo T, Nakagami Y, Ushiyama $\mathrm{T}$, et al: Inhibitory effect of adrenocorticotropin on corticotropin-releasing factor release from rat hypothalamus in vitro. Endocrinology 1986;118: 459-461.

20 Suda T, Tomori N, Yajima F, Ushiyama T, Sumitomo T, Nakagami Y, et al: A short negative feedback mechanism regulating corticotropin-releasing hormone release. J Clin Endocrinol Metab 1987;64:909-913.

21 Boscaro M, Sonino N, Paoletta A, Rampazzo A, Mantero F: Evidence for ultra-short loop autoregulation of adrenocorticotropin secretion in man. J Clin Endocrinol Metab 1988;66:255-257.

22 Morris DG, Kola B, Borboli N, Kaltsas GA, Gueorguiev M, McNicol AM, et al: Identification of adrenocorticotropin receptor messenger ribonucleic acid in the human pituitary and its loss of expression in pituitary adenomas. J Clin Endocrinol Metab 2003;88: 6080-6087.

23 Brook CGD, Clayton PE, Brown SB: Clinical Pediatric Endocrinology, ed 5. Oxford, Blackwell, 2005.

24 Davidai G, Kahana L, Hochberg Z: Glomerulosa failure in congenital adrenocortical unresponsiveness to ACTH. Clin Endocrinol (Oxf) 1984;20:515-520.

25 Xia Y, Wikberg JE: Localization of ACTH receptor mRNA by in situ hybridization in mouse adrenal gland. Cell Tissue Res 1996; 286:63-68. 
26 Reincke M, Beuschlein F, Menig G, Hofmockel G, Arlt W, Lehmann R, et al: Localization and expression of adrenocorticotropic hormone receptor mRNA in normal and neoplastic human adrenal cortex. J Endocrinol 1998;156:415-423.

27 Arvat E, Di Vito L, Lanfranco F, Maccario M Baffoni C, Rossetto R, et al: Stimulatory effect of adrenocorticotropin on cortisol, aldosterone, and dehydroepiandrosterone secretion in normal humans: dose-response study. J Clin Endocrinol Metab 2000;85:31413146 .

28 Weise K, Zaritsky A: Endocrine manifestations of critical illness in the child. Pediatr Clin North Am 1987;34:119-130.

-29 Perry R, Kecha O, Paquette J, Huot C, Van Vliet G, Deal C: Primary adrenal insufficiency in children: twenty years experience at the Sainte-Justine Hospital, Montreal. J Clin Endocrinol Metab 2005;90:3243-3250.

-30 Migeon CJ, Kenny EM, Kowarski A, Snipes CA, Spaulding JS, Finkelstein JW, et al: The syndrome of congenital adrenocortical unresponsiveness to ACTH. Report of six cases. Pediatr Res 1968;2:501-513.

- 31 Kelch RP, Kaplan SL, Biglieri EG, Daniels GH, Epstein CJ, Grumbach MM: Hereditary adrenocortical unresponsiveness to adrenocorticotropic hormone. J Pediatr 1972;81: 726-736.

-32 Crown A, Lightman S: Why is the management of glucocorticoid deficiency still con troversial: a review of the literature. Clin Endocrinol (Oxf) 2005;63:483-492.

- 33 Mountjoy KG, Robbins LS, Mortrud MT, Cone RD: The cloning of a family of genes that encode the melanocortin receptors. Science $1992 ; 257: 1248-1251$.

-34 Tsigos C, Arai K, Hung W, Chrousos GP: Hereditary isolated glucocorticoid deficiency is associated with abnormalities of the adrenocorticotropin receptor gene. J Clin Invest 1993;92:2458-2461.

- 35 Tsigos C, Arai K, Latronico AC, DiGeorge AM, Rapaport R, Chrousos GP: A novel mutation of the adrenocorticotropin receptor (ACTH-R) gene in a family with the syndrome of isolated glucocorticoid deficiency, but no ACTH-R abnormalities in two families with the triple A syndrome. J Clin Endocrinol Metab 1995;80:2186-2189.

-36 Weber A, Toppari J, Harvey RD, Klann RC, Shaw NJ, Ricker AT, et al: Adrenocorticotropin receptor gene mutations in familial glucocorticoid deficiency: relationships with clinical features in four families. J Clin Endocrinol Metab 1995;80:65-71.

-37 Naville D, Penhoat A, Barjhoux L, Jaillard C, Fontanay S, Saez J, et al: Characterization of the human ACTH receptor gene and in vitro expression. Endocr Res 1996;22:337-348.

- 38 Wu SM, Stratakis CA, Chan CH, Hallermeier KM, Bourdony CJ, Rennert OM, et al: Genetic heterogeneity of adrenocorticotropin $(\mathrm{ACTH})$ resistance syndromes: identification of a novel mutation of the ACTH receptor gene in hereditary glucocorticoid deficiency. Mol Genet Metab 1998;64:256-265.
Slavotinek AM, Hurst JA, Dunger D, Wilkie AO: ACTH receptor mutation in a girl with familial glucocorticoid deficiency. Clin Genet 1998;53:57-62.

40 Naville D, Penhoat A, Durand P, Begeot M: Three steroidogenic factor-1 binding elements are required for constitutive and cAMP-regulated expression of the human adrenocorticotropin receptor gene. Biochem Biophys Res Commun 1999;255:28-33.

41 Elias LL, Huebner A, Pullinger GD, Mirtella A, Clark AJ: Functional characterization of naturally occurring mutations of the human adrenocorticotropin receptor: poor correlation of phenotype and genotype. J Clin Endocrinol Metab 1999;84:2766-2770.

42 Naville D, Barjhoux L, Jaillard C, Faury D, Despert F, Esteva B, et al: Demonstration by transfection studies that mutations in the adrenocorticotropin receptor gene are one cause of the hereditary syndrome of glucocorticoid deficiency. J Clin Endocrinol Metab 1996;81:1442-1448.

43 Naville D, Barjhoux L, Jaillard C, Saez JM, Durand P, Begeot M: Stable expression of normal and mutant human ACTH receptor: study of ACTH binding and coupling to adenylate cyclase. Mol Cell Endocrinol 1997; 129:83-90.

44 Fluck CE, Martens JW, Conte FA, Miller WL: Clinical, genetic, and functional characterization of adrenocorticotropin receptor mutations using a novel receptor assay. J Clin Endocrinol Metab 2002;87:4318-4323.

-45 Yanovski JA, Yanovski SZ, Gold PW, Chrousos GP: Differences in the hypothalamic-pituitary-adrenal axis of black and white women. J Clin Endocrinol Metab 1993;77: 536-541.

46 Yanovski JA, Yanovski SZ, Harrington L, Gold PW, Chrousos GP: Differences in the hypothalamic-pituitary-adrenal axis of black and white men. Horm Res 1995;44: 208-212.

47 Naville D, Weber A, Genin E, Durand P, Clark AJ, Begeot M: Exclusion of the adrenocorticotropin (ACTH) receptor (MC2R) locus in some families with ACTH resistance but no mutations of the MC2R coding sequence (familial glucocorticoid deficiency type 2). J Clin Endocrinol Metab 1998;83: 3592-3596.

48 Weber A, Clark AJ: Mutations of the ACTH receptor gene are only one cause of familial glucocorticoid deficiency. Hum Mol Genet 1994;3:585-588.

49 Genin E, Huebner A, Jaillard C, Faure A, Halaby G, Saka N, et al: Linkage of one gene for familial glucocorticoid deficiency type 2 (FGD2) to chromosome $8 \mathrm{q}$ and further evidence of heterogeneity. Hum Genet 2002; 111:428-434.
0 Noon LA, Franklin JM, King PJ, Goulding NJ, Hunyady L, Clark AJ: Failed export of the adrenocorticotrophin receptor from the endoplasmic reticulum in non-adrenal cells: evidence in support of a requirement for a specific adrenal accessory factor. J Endocrinol 2002; 174:17-25.

51 Rached M, El Mourabit H, Buronfosse A, Blondet A, Naville D, Begeot M, et al: Expression of the human melanocortin-2 receptor in different eukaryotic cells. Peptides 2005; 26:1842-1847.

52 Metherell LA, Chapple JP, Cooray S, David A, Becker C, Ruschendorf F, et al: Mutations in MRAP, encoding a new interacting partner of the ACTH receptor, cause familial glucocorticoid deficiency type 2. Nat Genet 2005;37:166-170.

53 McLatchie LM, Fraser NJ, Main MJ, Wise A, Brown J, Thompson N, et al: RAMPs regulate the transport and ligand specificity of the calcitonin-receptor-like receptor. Nature 1998;393:333-339.

54 Saito H, Kubota M, Roberts RW, Chi Q, Matsunami H: RTP family members induce functional expression of mammalian odorant receptors. Cell 2004;119:679-691.

55 Behrens M, Bartelt J, Reichling C, Winnig M, Kuhn C, Meyerhof W: Members of RTP and REEP gene families influence functional bitter taste receptor expression. J Biol Chem 2006;281:20650-20659.

56 Roy S, Rached M, Gallo-Payet N: Differential regulation of the human adrenocorticotropin receptor [melanocortin-2 receptor (MC2R)] by human MC2R accessory protein isoforms alpha and beta in isogenic human embryonic kidney 293 cells. Mol Endocrinol 2007;21:1656-1669.

57 Huber C, Dias-Santagata D, Glaser A, O'Sullivan J, Brauner R, Wu K, et al: Identification of mutations in CUL7 in 3-M syndrome. Nat Genet 2005;37:1119-1124.

58 Fluck CE, Tajima T, Pandey AV, Arlt W, Okuhara K, Verge CF, et al: Mutant P450 oxidoreductase causes disordered steroidogenesis with and without Antley-Bixler syndrome. Nat Genet 2004;36:228-230.

59 Krude H, Biebermann H, Luck W, Horn R, Brabant G, Gruters A: Severe early-onset obesity, adrenal insufficiency and red hair pigmentation caused by POMC mutations in humans. Nat Genet 1998;19:155-157.

60 Yeo GS, Farooqi IS, Aminian S, Halsall DJ, Stanhope RG, O'Rahilly S: A frameshift mutation in MC4R associated with dominantly inherited human obesity. Nat Genet 1998;20: 111-112.

61 Lubrano-Berthelier C, Dubern B, Lacorte JM, Picard F, Shapiro A, Zhang S, et al: Melanocortin 4 receptor mutations in a large cohort of severely obese adults: prevalence, functional classification, genotype-phenotype relationship, and lack of association with binge eating. J Clin Endocrinol Metab 2006;91:1811-1818.

-62 Clark AJ, Metherell LA, Cheetham ME, Huebner A: Inherited ACTH insensitivity illuminates the mechanisms of ACTH action. Trends Endocrinol Metab 2005;16:451-457. 